\title{
METABOLISM OF ARABINOSYLADENINE IN HERPES SIMPLEX VIRUS-INFECTED AND UNINFECTED CELLS
}

\author{
CORRELATION WITH INHIBITION OF DNA SYNTHESIS AND ROLE IN \\ ANTIVIRAL SELECTIVITY
}

\author{
Pauline M. Schwartz*, Jean Novack, Charles Shipman, JR. and John C. Drach $\dagger$ \\ School of Dentistry and Interdepartmental Graduate Program in Medicinal Chemistry, The University \\ of Michigan, Ann Arbor, MI 48109, U.S.A.
}

(Received 6 June 1983; accepted 8 December 1983)

\begin{abstract}
The metabolism of $9-\beta$-D-arabinofuranosyladenine (ara-A, vidarabine) and its effects on DNA synthesis were compared in uninfected and herpes simplex virus type-1 (HSV-1)-infected KB cells. In the absence of an inhibitor of adenosine deaminase, ara-A was deaminated to $9-\beta$-Darabinofuranosylhypoxanthine and phosphorylated to ara-A-5'-mono-, di- and triphosphates in both types of cells. When an inhibitor of adenosine deaminase (coformycin) was added to cell cultures, nucleotides were the only metabolites detected-primarily the $5^{\prime}$-triphosphate of ara-A (aATP). Detailed studies performed in the presence of coformycin established that the net rate and extent of aATP formation were the same in uninfected and HSV-1-infected cells. After a 12-hr exposure to $50 \mu \mathrm{M}$ ara-A, intracellular concentrations of aATP were approximately $40 \mu \mathrm{M}$. Levels of aATP correlated directly with inhibition of total DNA synthesis. Approximately $0.7 \mu \mathrm{M}$ aATP was required for $50 \%$ inhibition of total DNA synthesis in both uninfected and HSV-1-infected cells. Following removal of ara-A-containing culture medium, aATP levels in uninfected cells declined with a half-life of $3.2 \mathrm{hr}$. In marked contrast, the half-life in HSV-1-infected cells was $9.3 \mathrm{hr}$; this may explain why as little as a 3hr exposure to ara-A resulted in a significant HSV-1 titer reduction. Taken together, the data show that when ara-A was removed from culture medium, levels of aATP persisted longer in HSV-1-infected cells thereby prolonging antiviral activity. This effect could be important in vivo where levels of ara-A oscillate with dosing schedule.
\end{abstract}

Vidarabine (ara-A) $¥$ is a clinically useful antiviral drug active against a broad spectrum of DNA viruses including HSV-1 [1-3]. It is effective in the therapy of several diseases caused by human herpes viruses including herpes keratitis, herpes encephalitis and varicella zoster in immunosuppressed patients $[3,4]$. The clinical efficacy of ara-A most likely is based upon its capacity to inhibit virus replication at concentrations which do not produce overt cytotoxicity in uninfected cells $[5,6]$. We have found that this selectivity is related directly to a preferential inhibition of viral DNA synthesis compared to cellular DNA synthesis $[7,8]$.

Although a number of possibilities have been explored [6,9-11], the biochemical basis for inhibition or alteration of DNA synthesis by ara-A involves the following mechanisms: (1) inhibition of viral and, to a lesser extent, cellular DNA poly-

\footnotetext{
* Present address: du Pont Pharmaceuticals, 500 South Ridgeway Ave., Glenolden, PA 19036.

+ Author to whom correspondence should be addressed at the School of Dentistry, The University of Michigan, Ann Arbor, MI 48109

\# Abbreviations: ara-A: $9-\beta$-D-arabinofuranosyladenine vidarabine; aAMP, aADP and aATP: the 5'-mono-, diand triphosphates of ara-A; ara- $\mathrm{H}$ : 9- $\beta$-Darabinofuranosylhypoxanthine; aHMP, aHDP and aHTP: the 5'-mono-, di- and triphosphates of ara-H; HSV-1: herpes simplex virus type-1; $\mathrm{IC}_{50}: 50 \%$ inhibitory concentration; PEI: polyethyleneimine; and pfu: plaque forming unit.

$\S$ W. M. Shannon, R. W. Brockman, G. Arnett and S.
} Shaddix, First Am. Soc. Virol. Meeting, Ithaca, NY (1982). merases by aATP [12-14], (2) inhibition of ribonucleoside diphosphate reductase by aATP\$, a mechanism which would potentiate the inhibition of DNA polymerase [15], (3) incorporation of aAMP residues into DNA [16] which retard the rate of chain elongation [17], and (4) inhibition of $S$-adenosyl-Lhomocysteine hydrolase [18] with subsequent reduction of methylation reactions resulting in cytotoxicity [19].

All of these mechanisms except (4) require the bioconversion of ara-A to aATP. Several groups have examined the phosphorylation of ara- $A$ in uninfected mammalian cells [20-23], but none have examined aATP formation in herpesvirus-infected cells. Furthermore, the preferential metabolism of ara-A by HSV-induced enzymes would provide a mechanism for achieving selective antiviral activity similar to that observed with a number of pyrimidine antimetabolites $[11,24,25]$. Therefore, we have explored this possibility by studying the deamination and phosphorylation of ara- $\mathrm{A}$ in the presence and absence of an adenosine deaminase inhibitor (coformycin [26]) in both HSV-1-infected and uninfected cultures of $\mathrm{KB}$ cells. In conjunction with this study, the relationship of ara-A metabolism to the degree of inhibition of DNA synthesis and HSV-1 replication also was investigated.

\section{MATERIALS AND METHODS}

Chemicals. Ara-A was provided through the courtesy of Dr. H. E. Machamer, Parke, Davis \& Co., 
Detroit, MI. aAMP and aHMP were gifts of Dr. R. L. Tolman. ICN Nucleic Acid Research Institute, Irvine, CA. aADP and aATP were purchased from Terra-Marine Bioresearch, La Jolla, CA. All other purine bases, nucleosides and nucleotides used as standards were obtained from Sigma Chemical Co., St. Louis, MO, or from P-L Biochemicals, Inc., Milwaukee, WI. $\left[2-{ }^{3} \mathrm{H}\right]$ Ara-A $(10-15 \mathrm{Ci} / \mathrm{mmole})$ and $\left[8^{-14} \mathrm{C}\right]$ adenine $(56 \mathrm{mCi} / \mathrm{mmole})$ were obtained from New England Nuclear, Boston, MA. [methyl $\left.-{ }^{3} \mathrm{H}\right]-$ Thymidine (7 and $45 \mathrm{Ci} / \mathrm{mmole})$ and $\left[2-{ }^{14} \mathrm{C}\right]-$ thymidine $(56 \mathrm{mCi} / \mathrm{mmole})$ were purchased from Nuclear Dynamics, Inc., El Monte, CA. Coformycin was a gift of Prof. $\mathrm{H}$. Umezawa, Institute of Microbial Chemistry, Tokyo, Japan.

Cell culture techniques and virus propagation. KB cells, an established human cell line derived from an epidermoid carcinoma of the mouth, and the HF strain of HSV-1 were the gift of Dr. G. H. Cohen, University of Pennsylvania, Philadelphia, PA. The routine growth and passage of $\mathrm{KB}$ cells and $\mathrm{BHK}$ $21 / 4$ cells, techniques used for the enumetation of cells, and the determination of cell viability have been described previously [7,8]. Monolayer or spinner (suspension) cultures of KB cells were maintained in medium supplemented with $10 \%$ extensively heat-inactivated calf serum in order to eliminate serum-associated adenosine deaminase [27]. The concentration of arginine in medium used with HSV-1-infected cells was doubled to $1.2 \mathrm{mM}$ to support virus replication [28]. The propagation and titration of HSV, protocols for measuring DNA synthesis, and the separation of viral and cellular DNA in HSV-1-infected cells also have been described previously $[7,8]$. All cell lines were screened periodically by Microbiological Associates, Bethesda, MD, and found to be free of mycoplasma.

Due to the known effects of ara-A on cell volume [29], the volume of KB cells growing in spinner cultures was determined. Wet mounts of cells and a calibrated micrometer were photographed through a Zeiss Photomicroscope II with transmitted light interference optics. Cell diameters were measured on whole field prints using a hand comparator fitted with a linear $\mathrm{mm}$ scale reticule. Cell diameters were converted to volume assuming spherical geometry. Measurements were made at 6,12 and $24 \mathrm{hr}$ after seeding uninfected of HSV-1-infected spinner cultures containing $0,0.5,10$, or $50 \mu \mathrm{M}$ ara-A plus $3.5 \mu \mathrm{M}$ coformycin. Measurements also were made with $10 \mu \mathrm{M}$ ara-A in the absence of coformycin. Several fields of cells were used for each set of conditions so that $>125$ cells per flask per time point were measured. Measurements from at least duplicate flasks were used in all determinations. Cell Chex (stabilized L cells, Streck Laboratories) with a volume of $2100 \pm 15 \mu \mathrm{m}^{3}$ were included as a reference standard. The volume of uninfected KB cells in the absence of drug was $3083 \pm 971 \mu \mathrm{m}^{3}$ in twentyone separate determinations. Volume increases of 12,27 and $42 \%$, respectively, were noted after $12 \mathrm{hr}$ in the presence of $0.5,10$ and $50 \mu \mathrm{M}$ ara-A plus $3.5 \mu \mathrm{M}$ coformycin. Volumes of HSV-1-infected cells increased markedly with time in the absence of ara-A but were similar to the above values in the presence of the drug.
Ara-A metabolism studies. Tritiated ara-A obtained for these studies contained 1.0 to $1.3 \%$ $\left[{ }^{3} \mathrm{H}\right]$ adenine (determined by silica gel TLC [30]). resulting in approximately $0.5 \mathrm{ng} / \mathrm{ml}$ in medium containing $2 \mu \mathrm{Ci} / \mathrm{ml}\left[{ }^{3} \mathrm{H}\right]$ ara-A. The $\left[{ }^{3} \mathrm{H}\right]$ adenine was removed by incubating medium containing [ $\mathrm{H}$ ]araA $(10-15 \mathrm{Ci} / \mathrm{mmole}), 3.5 \mu \mathrm{M}$ coformycin, $1.2 \mathrm{mM}$ arginine and $10 \%$ heat-inactivated calf serum with a suspension of $\mathrm{KB}$ cells (about $300 \times 10^{3}$ cells $/ \mathrm{ml}$ ). To monitor the duration of incubation needed to remove $\left[{ }^{3} \mathrm{H}\right]$ adenine, $\left[{ }^{14} \mathrm{C}\right]$ adenine was added to give $2.5 \mathrm{ng} /$ $\mathrm{ml}$, resulting in approximately $1000 \mathrm{cpm}\left[{ }^{14} \mathrm{C}\right]$ adenine $/ \mathrm{ml}$ of medium. When radioactivity from $\left[{ }^{14} \mathrm{C}\right]$ adenine was no longer detectable, it was assumed that the contaminating $\left[{ }^{3} \mathrm{H}\right]$ adenine was removed from the medium as well. The entire suspension culture was centrifuged and the supernatant medium used in subsequent metabolism experiments with fresh cells. During a 30-min incubation, greater than $90 \%$ of adenine-associated radioactivity was removed from the medium but no more than $5 \%$ of $\left[{ }^{3} \mathrm{H}\right]$-ara-A was lost during this preliminary incubation.

For studies on ara-A metabolism and DNA synthesis, a sterile stock solution of unlabeled ara-A plus $3.5 \mu \mathrm{M}$ coformycin was added to the $\left[{ }^{3} \mathrm{H}\right]$ ara- $\mathrm{A}$ containing preincubated medium to give the desired final drug concentration. Cells that previously had been virus or mock infected were added to the drugcontaining medium and were maintained at $37^{\circ}$ in spinner flasks. At selected times after initiation of the spinner cultures, separate aliquots of cells were removed for determination of cell viability, cell number (see above), DNA synthesis rates, and virus titers (described below), and for chromatographic determination of arabinosyl nucleotides.

Chromatographic assays were performed by removing $5-\mathrm{ml}$ aliquots of cell suspension and centrifuging at $600 \mathrm{~g}$ for $10 \mathrm{~min}$ at $4^{\circ}$. The supernatant fraction was carefully and entirely aspirated. The pellet was kept on ice and $0.1 \mathrm{ml}$ of ice-cold $70 \%$ ethanol was added. After vortexing, the samples were stored at $-20^{\circ}$ at least overnight. This procedure disrupted cell membranes as observed with the Zeiss photomicroscope. Soluble nucleotides did not increase if ethanol extracts were sonicated for $60 \mathrm{sec}$ at $20 \mathrm{kHz}$ in a Bronwill sonicator (Bronwill Scientific, Rochester, NY) set to deliver $70 \mathrm{~W}$ of accoustical power through a needle probe. After removal of cells, aliquots of culture medium also were brought to a final concentration of $70 \%$ ethanol and were stored at $-20^{\circ}$. Following storage, all samples were centrifuged to pellet precipitated materials before chromatographic assay.

Chromatographic identification of ara- $A$ metabolites. Nucleosides and bases were identified by TLC on silica gel plates (Analtech, Newark, DE) as described previously [30]. Stock solutions of ara-A. ara- $\mathrm{H}$, adenine and hypoxanthine were spotted on TLC plates along with 5- to $10-\mu$ aliquots of ethanolcontaining supernatant fractions from cells or culture medium. Following chromatography in the lower phase of chloroform-methanol-15\% ammonia ( $3: 2: 1$, by vol.), compounds were identified as detailed elsewhere [31] by fluorescence quenching and amount of label present in eluted fractions. Coinci- 
dence of radioactivity with reference compounds was taken as indicating identity of labeled and reference compounds.

Nucleotides were identified in a like manner by TLC on PEI-cellulose sheets (Brinkmann Instruments, Des Plains, IL). Stock aqueous solutions of AMP, dAMP, aAMP, ADP, dADP, aADP, ATP, dATP, aATP, IMP, dIMP , aHMP, IDP, dIDP, ITP, dITP were spotted along with 5- to $50-\mu$ l aliquots of ethanol-containing cell extracts. Two-dimensional chromatography was performed exactly as detailed earlier [32] and gave base line resolution of all nucleotides. Sections of the plastic-backed PEI plates were cut, placed into counting vials, and extracted with $2.0 \mathrm{ml}$ of $0.1 \mathrm{~N} \mathrm{HCl}$ in methanol for $15 \mathrm{hr}$ at $37^{\circ}$. Scintillation solution was added, samples were counted, and disintegrations per minute for each fraction were determined. Concentrations of arabinosyl nucleotides were calculated based upon the known specific activity of ara-A. The concentration of aATP in pmoles $/ 10^{6}$ cells was converted to $\mu$ moles/liter based upon the volume of KB cells presented above. The rate of aATP disappearance following removal of ara-A from culture medium was determined by linearly regressing the log of aATP concentration against time. Data points from four separate experiments with uninfected cells fit the individual regression lines with $r^{2}$ values $>0.91$. Values for experiments with HSV-1-infected cells were 0.69 for drug removal at $3 \mathrm{hr}$ and 0.85 and 0.98 for drug removal at $6 \mathrm{hr}$.

Determination of virus titer and rates of DNA synthesis. These two variables were determined in the same cultures used for studying ara-A metabolism. During incubation of cells with $\left[{ }^{3} \mathrm{H}\right]$ ara-A in spinner cultures, two additional 5- or 6-ml aliquots of cell suspension were removed. (Virus- and mockinfected cultures without ara-A also were included in all these experiments.) One set of aliquots was frozen at $-70^{\circ}$ for subsequent determination of virus titer as mentioned above. The other set of aliquots was placed in glass tubes containing $0.1 \mathrm{ml}$ of labeled thymidine to give a final concentration of $0.5 \mu \mathrm{Ci} / \mathrm{ml}$ $\left[{ }^{14} \mathrm{C}\right]$ thymidine or $2.0 \mu \mathrm{Ci} / \mathrm{ml}\left[{ }^{3} \mathrm{H}\right]$ thymidine. Concurrent studies published earlier [31] established that the effect of ara-A (plus coformycin) on DNA synthesis could be measured accurately by labeled thymidine incorporation at ara- $\mathrm{A}$ concentrations $<50 \mu \mathrm{M}$.

Immediately after cells were mixed with isotope, $100 \mu \mathrm{l}$ of the suspension was spotted in triplicate on filter paper circles for determination of background radioactivity. Tubes then were incubated in a $37^{\circ}$ water bath shaking at 200 excursions $/ \mathrm{min}$. After 0.5 or $1 \mathrm{hr}, 100 \mu \mathrm{l}$ of each suspension was spotted in triplicate on filter paper circles and processed as described $[7,8]$. Samples of $\left[{ }^{3} \mathrm{H}\right]$ ara-A-treated cells also were spotted on filter papers before and after the thymidine pulse exposure. Data were tabulated as radioactive thymidine incorporated into acid insoluble material per $10^{3}$ cells, and inhibition of DNA synthesis in drug-treated cultures was determined as a percent of that in cultures without drug.

Data analyses. Concentrations of aATP in uninfected and HSV-1-infected cells were compared using Student's $t$-test $[33,34]$. Dose-response relationships were constructed by linearly regressing probit values of the percent inhibition of DNA synthesis or HSV-1 titer reduction against log drug concentrations. $\mathrm{IC}_{50}$ concentrations and the $95 \%$ confidence intervals were calculated from the regression lines using the methods described by Goldstein [33]. Identity of any two dose-response curves was tested by calculating $P$ values for the equality of the regressions and slopes $[5,34]$.

\section{RESULTS}

Metabolism of ara-A in the presence and absence of coformycin. Preliminary experiments were performed to examine the metabolism of ara-A in mockinfected and HSV-1-infected cultures of KB cells. Following a 1-hr incubation of monolayer cultures with or without coformycin and selected concentrations of $\left[{ }^{3} \mathrm{H}\right] \mathrm{ara}-\mathrm{A}$, labeled nucleosides and nucleotides were characterized chromatographically. Chromatography of extracts from culture media and cells exposed to ara-A plus $3.5 \mu \mathrm{M}$ coformycin revealed the presence of $\left[{ }^{3} \mathrm{H}\right]$ ara- $A$ alone in culture media and $\left[{ }^{3} \mathrm{H}\right]$ ara-A plus ${ }^{3} \mathrm{H}$-labeled nucleotides in cells. In media and cells grown in the absence of coformycin, $\left[{ }^{3} \mathrm{H}\right]$ ara- $\mathrm{H}$ was the only additional compound detected accounting for $45 \%$ of the label. This metabolism was caused by cellular deamination of ara-A since serum adenosine deaminase was inactivated by heating [27]. $\left[{ }^{3} \mathrm{H}\right] \mathrm{aATP}$ was identified by chromatography of nucleotides in cell extracts. The amount of aATP formed increased with increasing concentrations of ara- $A$ and the presence of coformycin but otherwise did not vary greatly whether or not cells were infected with HSV-1. For example, when monolayer cultures were incubated with $0.2,10$ or $50 \mu \mathrm{M}$ ara-A plus coformycin, 0.24 , 8.7 and 30.3 pmoles aATP $/ 10^{6}$ cells, respectively, were formed in mock-infected cells compared to $0.21,11.3$ and 30.7 moles $/ 10^{6}$ cells in HSV-1infected cells. [ $\left.{ }^{3} \mathrm{H}\right] \mathrm{ATP}$ also was formed in all cultures and was approximately 2.5 times the amount of $\left[{ }^{3} \mathrm{H}\right] \mathrm{aATP}$. We do not, however, attribute the formation of $\left[{ }^{3} \mathrm{H}\right]-A T P$ to the metabolism of $\left[{ }^{3} \mathrm{H}\right]-$ ara-A. Rather $\left[{ }^{3} \mathrm{H}\right]$-ATP appeared to be formed as a consequence of the metabolic salvage of $\left[{ }^{3} \mathrm{H}\right]-$ adenine found as a $1.3 \%$ contaminant in the preparation of $\left[{ }^{3} \mathrm{H}\right]$ ara- $A$. In subsequent experiments (described below) where the contaminating $\left[{ }^{3} \mathrm{H}\right]-$ adenine was reduced to $<0.1 \%$ of $\left[{ }^{3} \mathrm{H}\right]$ ara-A (see Materials and Methods), the amount of $\left[{ }^{3} \mathrm{H}\right]$ ATP never was more than $10 \%$ of the amount of $\left[{ }^{3} \mathrm{H}\right]-$ aATP. No additional labeled nucleotides were detected in the cell extracts other than small amounts ( $<10 \%$ of the corresponding triphosphates) of aADP, aAMP, ADP, and AMP.

Phosphorylation of ara-A in mock-infected and $H S V-1$-infected $K B$ cells. More extensive studies on the metabolism of ara-A were performed using suspension (spinner) cultures of KB cells. In this and all subsequent experiments, coformycin was added to totally inhibit the deamination of ara-A. After virus or mock infection, cells were resuspended in medium containing $10 \mu \mathrm{M}\left[{ }^{3} \mathrm{H}\right]$ ara- $\mathrm{A}$, and samples of the cell suspensions were removed at selected 


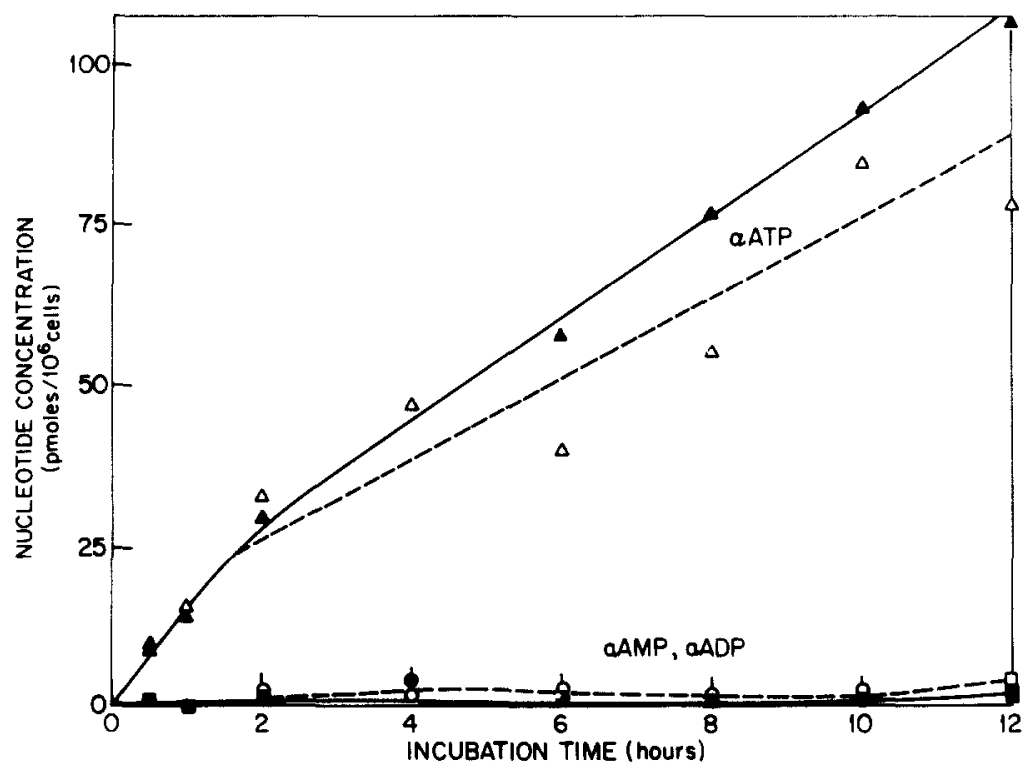

Fig. 1. Metabolism of ara-A by uninfected and HSV-1-infected KB cells. Spinner cultures of mockinfected (dashed lines, open symbols) and HSV-1-infected (solid lines, closed symbols) KB cells were suspended in culture medium containing $10 \mu \mathrm{M}\left[{ }^{3} \mathrm{H}\right]$ ara- $\mathrm{A}(2 \mu \mathrm{Ci} / \mathrm{ml})$ plus $3.5 \mu \mathrm{M}$ coformycin and were incubated at $37^{\circ}$. At the times indicated, $5-\mathrm{ml}$ aliquots of cells were removed and centrifuged, medium was aspirated, and cells were extracted with $70 \%$ ethanol. Labeled nucleotides were identified by two dimensional TLC. Key: aATP $(\triangle, \mathbf{\Delta})$, aADP $(\square, \mathbf{0})$, and $\operatorname{aAMP}(\mathrm{O}, \boldsymbol{\bullet})$.

times for chromatographic identification of labeled intracellular nucleotides. Tritiated aATP was the major metabolic product accounting for $>90 \%$ of the labeled nucleotides. Less than $10 \%$ of the label was associated with aAMP and aADP. Little or no label chromatographed with any other ribosyl, deoxyribosyl, or arabinosyl nucleoside-5'-mono-, di-, or triphosphate of adenine, hypoxanthine or guanine. Intracellular concentrations of aATP increased during the 12 -hr incubation period in both uninfected and HSV-1-infected cells (Fig. 1). Concentrations shown in Fig. 1 were converted to $\mu$ moles/liter based on cell volumes determined as described in Materials and Methods. At $1 \mathrm{hr}$, con-

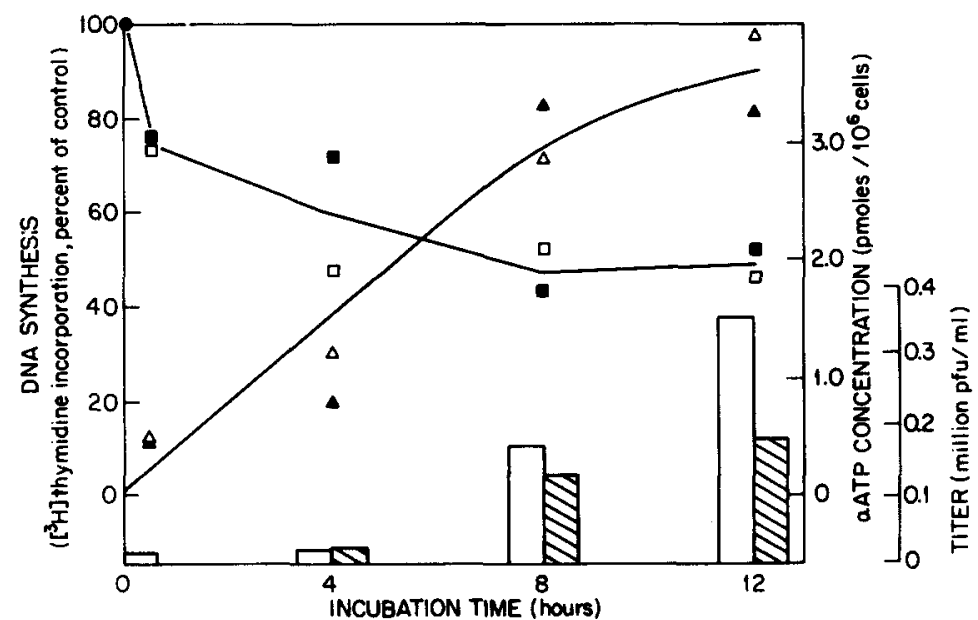

Fig. 2. Phosphorylation of ara-A plus inhibition of DNA synthesis and viral replication. Spinner cultures of mock-infected (open symbols) and HSV-1-infected (closed symbols) KB cells were incubated with $1 \mu \mathrm{M}\left[{ }^{3} \mathrm{H}\right]$ ara-A $(2 \mu \mathrm{Ci} / \mathrm{ml})$ plus $3.5 \mu \mathrm{M}$ coformycin for $12 \mathrm{hr}$ at $37^{\circ}$. Intracellular concentrations of aATP $(\triangle, \Delta)$, incorporation of $\left[{ }^{3} \mathrm{H}\right] \mathrm{d}$ Thd into acid-precipitable material $(\square, \boldsymbol{\square})$, and virus titers (open and hatched histograms respectively) were determined in the absence and presence of drug at all indicated times. In the absence of drug, an average of 1268 and $1570 \mathrm{cpm}$, respectively, were incorporated per $100 \mu \mathrm{l}$ of suspensions of mock-infected and HSV-1-infected cells during $0.5 \mathrm{hr}$ exposures to $2 \mu \mathrm{Ci} / \mathrm{ml}$ $\left[{ }^{3} \mathrm{H}\right] \mathrm{dThd}$. Common lines have been drawn through data from both mock-infected and HSV-1-infected cultures because of the similarity of measured values. Data at $12 \mathrm{hr}$ also are included in the doseresponse curves presented in Fig. 3. 


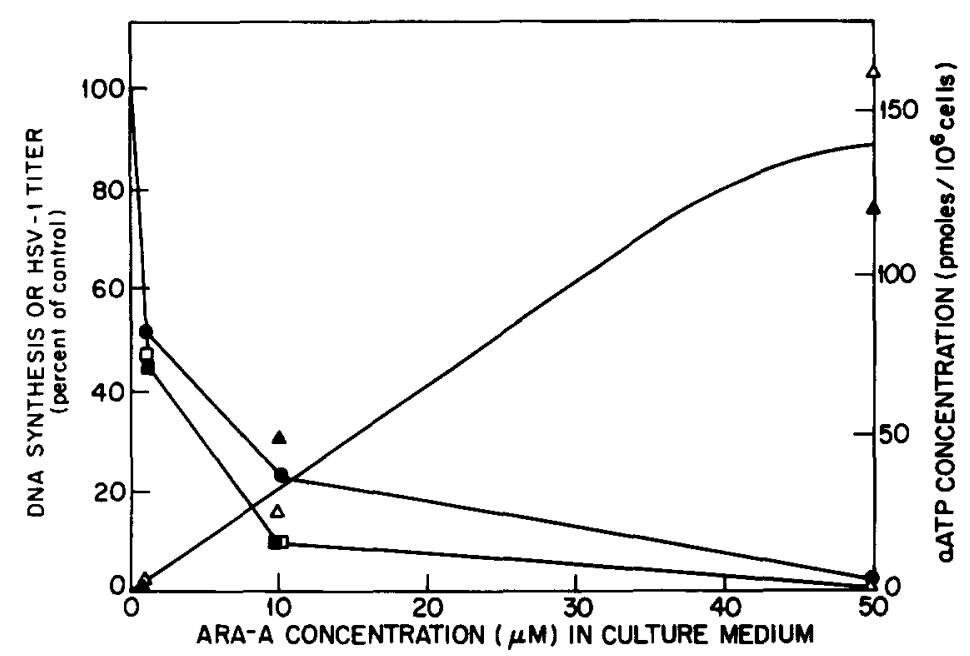

Fig. 3. Dose-response relationships between ara-A concentrations in culture media and aATP formation, inhibition of DNA synthesis, and HSV-1 titer reduction. Spinner cultures of mock-infected (open symbols) and HSV-1-infected (closed symbols) KB cells were incubated for $12 \mathrm{hr}$ with $0,1,10$ or $50 \mu \mathrm{M}\left[{ }^{3} \mathrm{H}\right]$ ara-A plus $3.5 \mu \mathrm{M}$ coformycin. Intracellular concentrations of aATP $(\Delta, \Delta)$, $\left[{ }^{3} \mathrm{H}\right] \mathrm{dThd}$ incorporation into acid precipitable material $(\square, \square)$, and virus titer $(\boldsymbol{O})$ were determined. Data obtained only at $12 \mathrm{hr}$ are presented.

centrations were 5.0 and $4.5 \mu \mathrm{M}$, respectively, in uninfected and HSV-1-infected cells, increasing to 20 and $26 \mu \mathrm{M}$, respectively, at $12 \mathrm{hr}$.

The rate of aATP synthesis during the initial hour of incubation was virtually identical in uninfected and HSV-1-infected cells (Fig. 1). The slightly greater amounts of aATP observed at later times in HSV-1-infected cells were not seen in subsequent experiments (Figs. 2-4). A comparison of data obtained in all experiments (Figs. 1-4 plus text) established that there were no differences in the amounts of aATP present in uninfected and HSV-1infected cells. After $1 \mathrm{hr}$ of incubation, the aATP concentration in uninfected cells was $1.08 \pm 0.35$ pmoles $/ 10^{6}$ cells (mean \pm S.D. normalized per $\mu$ mole ara-A/L culture medium) compared to $0.94 \pm 0.30$ pmole $/ 10^{6} \mathrm{HSV}$ - 1 -infected cells $(\mathrm{P}=$ $0.25, \mathrm{~N}=14$ observations each). At 10-12 hr, the amounts of aATP present in uninfected and infected cells were $3.7 \pm 2.3$ and $5.3 \pm 3.4$ pmoles $/ 10^{6}$ cells respectively $(\mathrm{P}=0.40, \mathrm{~N}=5$ and 7 observations respectively).

Correlation of aATP formation with inhibition of DNA synthesis and virus replication. Ara-A phosphorylation was compared to inhibition of DNA synthesis using spinner cultures of mock-infected and HSV-1-infected KB cells. In this way aATP formation, DNA synthesis, and HSV-1 titers could be examined as functions of virus infection, drug concentration, and time. In one such experiment, mock-infected and HSV-1-infected cells were incubated for $12 \mathrm{hr}$ in the presence of $0,1,10$, or $50 \mu \mathrm{M}$ ara-A (Figs. 2 and 3). Figure 2 presents the effects of $1 \mu \mathrm{M}$ ara-A different times. The intracellular levels of aATP increased at the same rate in mockinfected and HSV-1-infected cells. At the same time, DNA synthesis and HSV-1 titers fell in the presence of ara-A. At 10 and $50 \mu \mathrm{M}$ ara-A, similar temporal relationships were observed but levels of aATP were

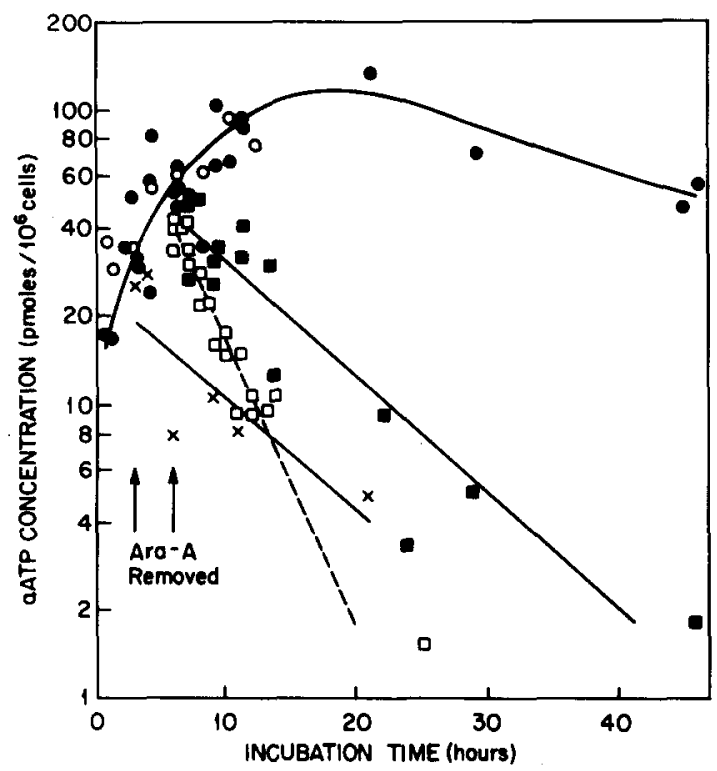

Fig. 4. Retention of intracellular aATP by uninfected and HSV-1-infected cells. Spinner cultures of cells were incubated at $37^{\circ}$ without and with $10 \mu \mathrm{M}\left[{ }^{3} \mathrm{H}\right]$ ara-A $(2 \mu \mathrm{Ci} / \mathrm{ml})$ plus $3.5 \mu \mathrm{M}$ coformycin. At 3 or $6 \mathrm{hr}$, each culture was divided into two portions, and the cells in one portion were removed from the original medium by two cycles of centrifugation and resuspension in drug-free medium. Incubation of drug-containing and drug-free cultures was continued. Concentrations of aATP and virus titers were determined using aliquots of cells removed at the times indicated. aATP concentrations are presented for mockinfected $(O)$ and HSV-1-infected (O) cells incubated without removal from ara-A-containing medium and for uninfected $(\square)$ and HSV-1-infected cells removed from drug at $3(x)$ or $6(\square) \mathrm{hr}$. Data from four experiments with uninfected cells and two with infected cells were combined to generate the regression lines which begin at $6 \mathrm{hr}$. 


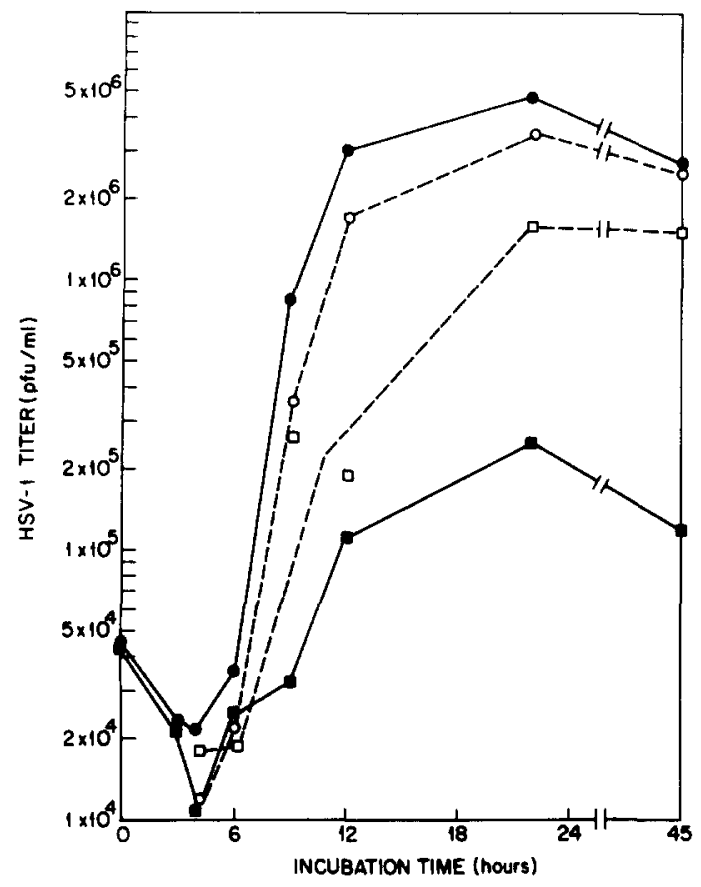

Fig. 5. Effect of drug removal on titers of HSV-1. Virus titers were measured in the experiment involving drug removal at $3 \mathrm{hr}$ described in the legend to Fig. 4. Titers are given for cells incubated in the following ways: (1) in the absence of drug (O), (2) in the absence of drug but subjected to the wash procedure $(O),(3)$ in the presence of $10 \mu \mathrm{M}$ ara-A (ם), and (4) washed free of drug at $3 \mathrm{hr}(\square)$.

higher and inhibition of DNA synthesis and virus replication were greater (data not shown). Data obtained at the last time period $(12 \mathrm{hr})$ are presented as dose-response curves in Fig. 3. Increasing the concentration of ara- $\mathrm{A}$ in culture media resulted in higher intracellular levels of aATP and correspondingly greater inhibition of DNA synthesis and virus replication.

The retention of aATP in uninfected and HSV-1infected cells was compared following the removal of ara-A from the culture medium. In four experiments, removal of $10 \mu \mathrm{M}$ ara-A from uninfected cells after a 6-hr incubation resulted in a decline of aATP with a half-life of $3.2 \pm 0.14 \mathrm{hr}$ (mean \pm S.D. of half-lives determined in the separate experiments) (Fig. 4). In contrast, in three separate experiments with HSV-1infected cells, removal of $10 \mu \mathrm{M}$ ara-A at 3 or $6 \mathrm{hr}$ caused a decline in aATP levels with a half-life of $9.3 \pm 0.63 \mathrm{hr}$ (Fig. 4). The difference between the two half-lives is highly significant $(P<0.0001)$. These values compare to aATP half-lives of 1.7 or 13-15 hr, respectively, in uninfected $\mathrm{CHO}$ cells or human lymphoblastoid cells observed by Plunkett and coworkers $[35,36]$.

Removal of ara-A after a 3-hr exposure to drug reduced but did not eliminate antiviral activity. Figure 5 illustrates that the presence of $10 \mu \mathrm{M}$ araA for $3 \mathrm{hr}$ resulted in an approximate $50 \%$ decline in virus titer compared to a $>95 \%$ reduction in titer in cells exposed to drug for the entire incubation period. The 9-hr half-life of aATP in infected cells may explain why only a 3-hr exposure to drug resulted in a significant reduction in virus titer.

The relationships between inhibition of DNA synthesis and intracellular aATP levels were examined in more detail by linear regression analysis. Data from five separate experiments were used to construct lines of best fit as functions of intracellular aATP concentrations for inhibition of DNA synthesis in uninfected cells and inhibition of total DNA

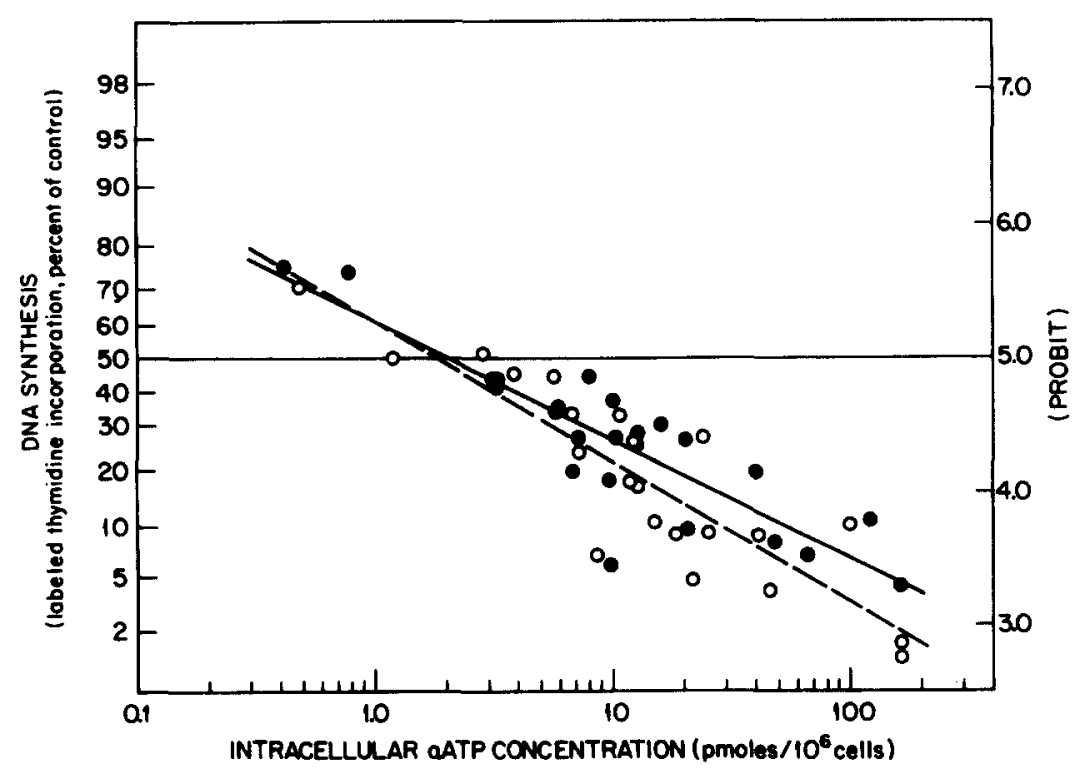

Fig. 6. Correlation of intracellular aATP levels with inhibition of DNA synthesis. Intracellular concentrations of aATP were compared to inhibition data by linearly regressing probit values of percent of control of DNA synthesis against log aATP concentrations. Data were obtained in five separate experiments (including those presented in Fig. 2-4) in which paired observations were made on aATP concentrations and DNA synthesis. Key: inhibition of DNA synthesis in uninfected $\left(O_{-}-O\right)$ or HSV1 -infected KB cells ( 
synthesis in HSV-1-infected cells. Figure 6 illustrates that the data points defined straight lines in classical dose-response relationships, i.e. higher intracellular concentrations of aATP were associated with greater inhibition of DNA synthesis (coefficients of correlation were -0.89 and -0.87 for mock-infected and HSV-1-infected cells respectively). Tests for coincidence of the lines showed no difference between the two dose-response lines (equality of slopes, $\mathrm{P}=0.32$; equality of regressions, $\mathrm{P}=0.13$ ). $\mathrm{IC}_{50}$ concentrations (and corresponding $95 \%$ confidence intervals) were calculated from the regression data and also showed no significant difference. The values were $1.8(0.9$ to 3.0$)$ and $2.0(1.1$ to 3.2$)$ pmoles aATP $/ 10^{6}$ cells, respectively, for inhibition of DNA synthesis in mock-infected cells and in HSV1 -infected cells. Assuming no drug-induced cell volume increase at these low drug concentrations, the IC $_{50}$ concentrations correspond to intracellular aATP levels of 0.6 to $0.7 \mu \mathrm{M}$.

\section{DISCUSSION}

Ara-A was metabolized to ara- $\mathrm{H}$ plus adenine nucleotides in both uninfected and HSV-1-infected $\mathrm{KB}$ cells. Because the same amount of ara- $\mathrm{H}$ was formed in both mock- and HSV-infected cells, we obtained no evidence for the induction of a viral adenosine deaminase. In the presence of coformycin, only adenine nucleotides were found in both cell types. When contaminating $\left[{ }^{3} \mathrm{H}\right]$ adenine was reduced to $<10 \%$ of the label in $\left[{ }^{3} \mathrm{H}\right]$ ara- $\mathrm{A}$ preparations, ara-A was anabolized almost exclusively to adenine arabinosyl nucleotides. A small amount of labeled ribosyl nucleotides (primarily $\left[{ }^{3} \mathrm{H}\right]$ ATP) also were detected, suggesting that the remaining $\left[{ }^{3} \mathrm{H}\right]$ adenine was salvaged efficiently by adenine phosphoribosyltransferase. Alternatively, ara-A could have been converted to ribosyl derivatives via the action of a purine nucleoside phosphorylase and reutilization of the purine base. Older observations that ATP formed from ara-A and subsequently was incorporated into RNA $[20,37]$ were attributed to the reutilization of labeled adenine arising from the phosphorolysis of ara-A [38].

We detected no radioactivity associated with hypoxanthine arabinosylnucleotides (aHMP, aHDP or aHTP) whether coformycin was present or not. Although neither aHDP nor aHTP were available as reference compounds, the TLC system used for the present study would have detected these nucleotides. This observation is in contrast to that of Chang and Glazko [39] who found aHMP in human erythrocytes incubated with ara-A in the absence of an adenosine deaminase inhibitor. It also contrasts with the observation of Müller et al. [40] that intracellular metabolites of ara-A consisted of $13 \%$ aHTP and $6 \%$ aHMP plus aHDP following incubation of L5178Y cells with $1.5 \mu \mathrm{M}$ ara-A.

aATP accumulated to the same extent in both uninfected and HSV-1-infected cells for $12 \mathrm{hr}$ when incubated with concentrations of ara-A as high as $50 \mu \mathrm{M}$; under these conditions the concentration of aATP was 130 pmoles $/ 10^{6}$ cells, approximately $40 \mu \mathrm{M}$. Plunkett et al. [36] reported that, within $3 \mathrm{hr}$, maximal levels of aATP $\left(200-250\right.$ pmoles $/ 10^{6}$ cells $)$ were achieved when CCRF-CEM cells were incubated with $100 \mu \mathrm{M}$ ara-A. These data suggest that cells may not concentrate ara-A nucleotides above the concentration of the nucleoside in the medium and that aATP pools may be saturable.

We have demonstrated previously that ara-A selectivity inhibits viral DNA synthesis and virion replication in $\mathrm{KB}$ cells $[5,7,8]$. For example, 3-5 $\mu \mathrm{M}$ ara-A was required to inhibit total DNA synthesis in uninfected and HSV-1-infected cells by $50 \%$ whereas $0.9 \mu \mathrm{M}$ inhibited viral DNA synthesis by $50 \%$ [8]. The present investigation showed that time- and dose-dependent formation of aATP correlated with inhibition of total DNA synthesis in both virusinfected and uninfected cells and with reduction of virus titers in infected cells. Fifty percent inhibition of total DNA synthesis was observed when the intracellular concentration of aATP was approximately 2 pmoles $/ 10^{6}$ cells, or approximately $0.7 \mu \mathrm{M}$. By extrapolating to our previous studies in HSV-1infected cells [8], we would expect a 3- to 5-fold lower concentration of aATP, roughly $0.2 \mu \mathrm{M}$, to inhibit viral (only) DNA synthesis in KB cells by $50 \%$. This value is remarkably consistent with $K_{i}$ concentrations of 0.14 and $0.33 \mu \mathrm{M}$ aATP for inhibition of isolated HSV-1 DNA polymerase reported by Müller et al. [41] and by Ostrander and Cheng [14] respectively. The $\mathrm{IC}_{50}$ concentrations of 1.8 and 2.0 pmoles aATP $/ 10^{6}$ cells (Fig. 6) also are consistent with the $\mathrm{IC}_{50}$ value of 3 pmoles aATP $/ 10^{6}$ cells found by Plunkett et al. [36] for inhibition of thymidine incorporation in uninfected human lymphoblastoid cells.

In addition to the known preferential inhibition of HSV DNA polymerase and ribonucleotide reductase by aATP, the current work has illuminated another possible mechanism which may contribute to antiviral specificity. Although the observed, net rate and extent of aATP accumulation were the same in uninfected and HSV-1-infected cells, the rate of aATP disappearance following drug removal from culture medium was three times more rapid in uninfected cells. (By implication, the actual rate of aATP synthesis also must have been more rapid in uninfected cells.) Like the preferential phosphorylation of other antiviral nucleosides in $\mathrm{HSV}$-infected cells $[11,24,25]$, the preferential degradation of aATP in uninfected cells could play a significant role in antiviral specificity.

This "reverse" type of specificity may not be important in vitro where aATP degradation is more than offset by synthesis from a virtually constant pool of ara-A in culture medium. In experimental animals and humans, however, where levels of araA oscillate with dosing schedule, a more prolonged aATP half-life in infected cells would increase the crucial time during which sufficient aATP would be present to block DNA synthesis and virion production. In uninfected cells, the shorter half-life would be critical in reducing cytotoxic effects of the drug because a short period of unbalanced growth may be reversible. It already has been established that both the concentration of aATP and the duration of its exposure are critical determinants for the cytotoxicity of ara-A in uninfected cells [42]. Thus, a differential kinetic effect between uninfected and 
HSV-infected cells would give rise to greater inhibition in HSV-infected cells. Combined with preferential inhibition of viral enzymes by aATP, inhibition of virion production at non-toxic drug levels should follow. Therefore, scheduling of ara-A relative to the initiation of virion replication may be an important factor in achieving selectivity against infections in vivo.

Acknowledgements-This work was supported by Public Health Service Grant DE 02731 from the National Institute of Dental Research. P. M. S. was supported in part by Public Health Service Training Grant GM 02010 from the National Institute of General Medical Sciences and was an AFPE Pharmaceutical Manufacturers Association Fellow. We thank Mark A. Thomas for performing the cell volume determinations and Steven R. Turk and Namat B. Katlama for expert assistance with selected aATP determinations.

\section{REFERENCES}

1. W. M. Shannon, in Adenine Arabinoside: An Antiviral Agent (Eds. D. Pavan-Langston, R. A. Buchanan and C. A. Alford, Jr.), p.1. Raven Press, New York (1975).

2. B. J. Sloan, in Adenine Arabinoside: An Antiviral Agent (Eds. D. Pavan-Langston, R. A. Buchanan and C. A. Alford, Jr.), p. 45. Raven Press, New York (1975).

3. R. A. Buchanan and F. Hess, Pharmac. Ther. 8, 143 (1980).

4. R. Whitley, C. Alford, F. Hess and R. Buchanan, Drugs 20, 267 (1980)

5. J. C. Drach and C. Shipman, Jr., Ann. N.Y. Acad. Sci. 284, 396 (1977)

6. R. A. Smith, R. W. Sidwell and R. K. Robins, A. Rev. Pharmac. Toxic. 20, 259 (1980)

7. C. Shipman, Jr., S. H. Smith, R. H. Carlson and J. C. Drach, Antimicrob. Agents Chemother. 9, 120 (1976).

8. P. M. Schwartz, C. Shipman, Jr. and J. C. Drach, Antimicrob. Agents Chemother. 10, 64 (1976).

9. T. W. North and S. S. Cohen, Pharmac. Ther. 4, 81 (1979).

10. W. E. G. Müller, in Antiviral Agents and Viral Diseases of Man (Eds. G. J. Galasso, T. C. Merigan and R. A. Buchanan), p. 77. Raven Press, New York (1979).

11. J. C. Drach, A. Rep. med. Chem. 15, 149 (1980).

12. W. E. G. Müller, R. K. Zahn, K. Bittlingmaier and D. Falke, Ann. N.Y. Acad. Sci. 284, 34 (1977).

13. C. M. Reinke, J. C. Drach, C. Shipman, Jr. and A. Weissbach, in Oncogenesis and Herpesviruses III, Part 2 (Eds. G. DeThe, W. Henle and F. Rapp), p. 999. IARC Press, Lyon (1978)

14. M. Ostrander and Y-C. Cheng, Biochim. biophys. Acto 609, 232 (1980).
15. C-H. Chang and Y-C. Cheng. Cancer Res. 40, 3555 (1980).

16. J. C. Pelling, J. C. Drach and C. Shipman, Jr. . Virology 109, 323 (1981).

17. D. Derse and Y-C. Cheng, J. biol. Chem. 256, 8525 (1981).

18. M. S. Hershfield, J. biol. Chem. 254, 22 (1979).

19. C. E. Cass, M. Selner, P. J. Ferguson and J. R. Phillips, Cancer Res. 42, 4991 (1982)

20. W. Plunkett and S. S. Cohen. Cancer Res. 35, 415 (1975).

21. L. M. Rose and R. W. Brockman, J. Chromat. 133, 335 (1977)

22. W. E. G. Müller, R. K. Zahn, J. Arendes, A. Maidhof and H. Umezawa, Hoppe-Seyler's Z. physiol. Chem. 359, 1287 (1978).

23. V. Verhoef, J. Sarup and A. Fridland, Cancer Res. 41 4478 (1981).

24. Y-C. Cheng, Ann. N.Y. Acad. Sci. 284, 594 (1977).

25. E. DeClercq, Biochem. J. 205, 1 (1982).

26. H. Nakamura, G. Koyama, Y. Iitaka, M. Ohno, N Yagisawa, S. Kondo, K. Maeda and H. Unezawa, $J$. Am. chem. Soc. 96, 4328 (1974).

27. P. M. Schwartz, C. Shipman, Jr., R. H. Carlson and J. C. Drach. Antimicrob. Agents Chemother. 5, 337 (1974).

28. R. J. Courtney, R. M. McComb and M. BenyishMelnick, Virology 43, 356 (1971).

29. A. Doering, J. Keller and S. S. Cohen, Cancer Res. 26, 2444 (1966).

30. J. C. Drach and J. M. Novack, Analyt. Biochem. 52, 633 (1973)

31. J. C. Drach, M. A. Thomas, J. W. Barnett, S. H. Smith and C. Shipman, Jr., Science 212, 549 (1981).

32. P. M. Schwartz and J. C. Drach, J. Chromat. 106, 200 (1975).

33. A. Goldstein, in Biostatistics: An Introductory Text, $\mathrm{p}$ 156. Macmillan, New York (1964).

34. D. J. Fox and K. E. Guire, in MIDAS: Michigan Interactive Data Analysis System, p. 164. The Statistical Research Laboratory of The University of Michigan, Ann Arbor (1976).

35. D. S. Shewach and W. Plunkett, Biochem. Pharmac. 28, 2401 (1979)

36. W. Plunkett. S. Chubb, L. Alexander and J. A Montgomery, Cancer Res. 40, 2349 (1980).

37. J. J. Brink and G. A. LePage, Cancer Res. 24, 312 (1964).

38. G. A. LePage, Can. J. Biochem. 48, 75 (1970).

39. T. Chang and A. J. Glazko, Res. Commun. Chem. Path. Pharmac. 14, 127 (1976).

40. W. E. G. Müller, J. Arendes, A. Maidhof, R. K. Zahn and W. Geurtsen, Chemotherapy 27, 53 (1981).

41. W. E. G. Müller, R. K. Zahn and D. Falke, Virology 84, 320 (1978).

42. D. S. Shewach and W. Plunkett, Cancer Res. 42, 3637 (1982). 